\title{
The Alternatives for Urban Green Space in Riverside Area of Banjarmasin to Create a Sustainable City
}

\author{
Hanny Maria Caesarina ${ }^{1, *}$ Dienny Redha Rahmani ${ }^{1}$
}

\author{
${ }^{1}$ Urban and Regional Planning Department, University of Muhammadiyah Banjarmasin, 70582, Indonesia \\ *Corresponding author. Email: hanny.planarch@gmail.com
}

\begin{abstract}
Green space as one of the indicators of sustainable city in riverside area is very important to Banjarmasin, the city of thousands river. However, due to the limited space, no other form of urban green space founded in the riverside area of the city other than greeneries. This research aimed to identify the alternatives of urban green space in riverside area that will be useful towards a sustainable city. Descriptive qualitative method was used in this research. Series of field research and observation were done, and interview with the local people. The data then analyzed with triangulation method. The result shows that urban green space in riverside area in Banjarmasin must accommodate the space of river to create some forms of green space such as floating communal space and green corridor along the river. A greener neighborhood is important for sustainable city. This research can be useful for to plan urban green space in riverside cities in Indonesia, especially in Kalimantan where a lot of cities are directly connected to the local river. Planning and design for riverside cities should consider to put more attention to connect its green space and river.
\end{abstract}

Keywords: Urban, Green Space, Riverside, Sustainable City.

\section{INTRODUCTION}

Banjarmasin already famous as the city of thousand rivers even before the independence of Indonesia in 1945. There are so many large and smaller river across the city which affecting the activity of the local people. During the colonial era, Banjarmasin developed into a harbor city by the Dutch which has Martapura river as the main river. People are doing trade and using river as the main transportation and settlements. Due to the rapid development in the city, these settlements are now already considered as traditional settlements compared to other urban "modernized" area in Banjarmasin [1][2]. However, the situation is already different from the past. There is no more land available alongside the riverside area. The traditional settlements become very dense and left no more space for green space. This situation almost similar to other cities in the world which need to deal with high density settlements along riverside area [3], [4]. Green space itself is one of the indicators in 17 Sustainable Development Goals (SDGs) no 11, sustainable cities and communities. Sustainable cities require about $20-30 \%$ for green space in urban area.

The local Government of Banjarmasin already tried to improve the quality of the riverside area, especially in the settlements. In 2018 they started the project called
"Kampung Hijau/Green Village" in one of the districts of Banjarmasin [4], [5]. This project renovated the settlements along the riverside area and adding greeneries to the area. Nevertheless, it seems not enough for the area. The greeneries only functioned aesthetically and not ecologically affecting the riverside area. It is clear that there is no land available to create green space. On the contrary, Banjarmasin has a lot of space above the river. Martapura river is 100-meter-wide and in the center of the city, the river is only used for tourism, water transportation, and floating market. The bigger boats are not allowed to enter the city center. This means, the river could be potential as one of the alternatives to provide green space in Banjarmasin. The question is, how can be the space above the river substitute the function of green space in Banjarmasin? Therefore, this research aimed to identify the alternatives of urban green space in riverside area that will be useful towards a sustainable city by considering the space above the river.

\section{METHOD}

This research aimed to identify the alternatives of urban green space in riverside area that will be useful towards a sustainable city. Descriptive qualitative method was used in this research. Literature research was 
done to identify any alternatives where green space can be combined with blue space, like river, lake or pond. Guidelines by the Minister of General Public Affair about green space also reviewed. This research was supposed to conduct field research for 4 to 5 months from January to June 2020. The Covid-19 forced the researcher to stop doing field research since April 2020. Fortunately, since July to September 2020, the new normal policy allowed the researcher to continue doing field research, observation and interview with the local people by following the health protocol.

According to the local people, while being locked down, they realize that they really need some kind of open space and green space in their environment. The locals were asked to fill questionnaire about sustainable urban green space, where the variables were derived from Sustainable Development Goals (SDGs) and Urban Green Space variables using Likert scale. Five districts in Banjarmasin participated in the questionnaire, which were West Banjarmasin District (WBD), East Banjarmasin District (EBD). North Banjarmasin District (NBD), South Banjarmasin District (SBD), and Central Banjarmasin District (CBD). Interviews with the experts were intended to acknowledge the probability of using the space above the river for green space in urban area where very limited space are still available for development. All of the data analyzed with triangulation method to define the best solution and alternatives for the riverside in urban area.

\section{RESULT AND DISCUSSION}

\subsection{Alternatives for Urban Green Space in Riverside Area}

According to the Urban Green Space guidelines, river is namely as blue space and it supposed to have its own guidelines. Still, there are no regulations about blue space[6]. It only mentions the riparian area along the riverside, which should have greenbelt to avoid the possibility of flood. The urban area in Banjarmasin also has riparian area but only around the estuary. The riverside in the city center is dominated by the settlements and promenade where the problem of providing green space occurred. The South Kalimantan Spatial Planning Policy [7] stated about providing space for urban space through land acquisition for public green space in each district which still has available space. The local Government mentioned the importance of a sustainable waterfront city in their Mid Term City Plan. Every planning and development in Banjarmasin should put river first which based on the sustainability principle. This included the settlements in riverside area which is part of the cultural heritage site and buildings. The city should have urban parks and thematic parks in the city, but it was not specifically mention about green and blue space. Therefore, the Local Government already put attention in adding public urban green space in each district as stated in the new spatial planning policy but still not considering blue space as active area for the city.

The main problem of the existing condition in the riverside area is the limited space of land for green space and the large space of the river. The riverside area is dominated by settlements area, commercial area and tourism area. In planning, river can be functioned as ecological system and also functional space like recreation, sports, etc. The plan is called "the green-blue infrastructure", which elaborate the blue space and green space to avoid flood[8]-[10]. For long term planning, flood is another thing need to be considered for the locals who lives along riverside area in Banjarmasin. As can be seen from Table.1, this research identified the local perception index of sustainable green space to obtain how the locals think about green space. The questions were arranged based on the indicator in Sustainable Development Goals (SDGs) and green space criteria. The result shows that the best index is for social aspect and environmental aspect, while the lowest index is spatial aspect. This data also relevant with the existing condition where it is almost impossible to provide green space on land along the riverside area. The blue space on the other hand, has plenty space and the locals already familiar with the nature condition.

The analysis shows that the criteria for urban green space in riverside should consider: space (urban green space need to be fit in a small space); using space above the river (this will depend on condition of water surface);

Table 1. Local Perception Index on Riverside’s Sustainable Green Space (Source: Analysis, 2020)

\begin{tabular}{crrrrrr} 
Variables & & \multicolumn{3}{c}{ Index } & & \\
& WBD & EBD & NBD & SBD & CBD & Average \\
\hline Environmental Aspect & 79 & 80 & 75 & 84 & 89 & 81.4 \\
Lifestyle Aspect & 70 & 73 & 75 & 74 & 80 & 74.4 \\
Social Aspect & 88 & 84 & 85 & 87 & 92 & 87.2 \\
Equity Aspect & 56 & 56 & 58 & 57 & 60 & 57.4 \\
Satisfaction Aspect & 67 & 67 & 68 & 68 & 68 & 67.6 \\
Spatial Aspect & 41 & 40 & 41 & 43 & 49 & 42.6 \\
Participatory Planning Aspect & 56 & 55 & 55 & 57 & 57 & 57 \\
\hline
\end{tabular}


resilient function (not just as green space, but can also be used for social space and preventing flood). These alternatives ha to iventegrate the green and blue space. Some researches mentioned about the how the blue and green infrastructure work together [10], [11]. Regardless, blue space needs to consider the condition of the water, whether it is calm water, or flowing water with streams like river. The condition of the river in Banjarmasin are divided into 3 different character, calm water, low stream and moderate stream. The streams in Martapura river in Banjarmasin are caused by water transportation and other activities in the river. Considering the winding and meandering river of Martapura river, means that each riverside area in Banjarmasin will need different alternatives.

Based on literature review and interviews with the experts, the urban green space in riverside area can come in several alternatives:

1. Side yard or green belt along riverside area. This alternative can work well in riparian area, where the settlements still has some land around each site of the house. Big trees and shrubs can be planted to create sun shading these trees also can help preventing flood. This alternative can work both in a big or small space and best in all water condition.

2. Floating garden/farming. There is some study about floating garden, and can work effectively in a calm water surface area (blue space). By putting anchor below the surface media for vegetation, there are plenty of vegetation can be planted, such as water spinach, flowers, etc [12], [13]. However, this alternative has its own weaknesses which are: can only place in a calm water environment and needs continuous maintenance, especially if it is regarding floating farming.

3. Communal space. As part of the promenade, floating communal spaces can function as the social space, as well as green space [14]. This alternative can place in moderate stream area and needs a good floating structure made from wood or concrete.

4. Vertical gardens by using media or pergolas which [15], [16]. This alternative requires very small space for installation and need continuous maintenance. In tropical humid climate, there are also possibilities of insects or snakes which tend to like this kind of plantation. Therefore, vertical gardens also need special treatments for avoiding bugs and others.

\subsection{Discussion}

In order to create a sustainable city, one of the agenda of SDGs is to provide urban green space for not less than $30 \%$. There is no specific previous research mentioned about how to create green space along the river. They were mostly related to riparian area or promenade. How about the special condition like Banjarmasin which has very dense settlements along riverside area? the settlements are exactly stands above the river and not in the riparian area. This research shows that, the riverside area of Banjarmasin will need a special guideline for its urban green space by cooperating blue space as part of green space.

The result of this research shows that for the special case in Banjarmasin, it might need a special approach too. The alternatives of side yard, floating garden/farming, communal space and vertical garden each has their own strength and weaknesses. These forms of urban green space cannot be counted as part of $30 \%$ urban green space of the city. Nevertheless, the alternatives show in this research may give so many positive impacts to the environment. Floating garden or farming can be very much useful for the locals [17][18]. Besides "greening" the area, this alternative also gives opportunity to plant any kind of vegetation all years long. During the dry season, the local can still use the river as their plantation media. With good planning, including community involvement, floating garden and farming can be a very a good alternative. Floating communal space will need a little bit extra space above the river, but it can provide open space too for the locals to do their activities[19][21]. Studies on other countries shows that floating communal space can be used for social gathering, gardening, etc. As long it will not have any other function than open space, floating communal space can be useful for the locals. It can also integrate vertical garden like in China [15], [22], [23] where they created green neighborhood through vertical garden.

\section{CONCLUSION}

The result shows that urban green space in riverside area in Banjarmasin must accommodate the space of river to create some forms of green space such as floating communal space and green corridor along the river, as also be called as green-blue infrastructure planning [24] [26]. A greener neighborhood is important for sustainable city. This research can be useful for to plan urban green space in riverside cities in Indonesia, especially in Kalimantan where a lot of cities are directly connected to the local river. Planning and design for riverside cities should consider to put more attention to connect its green space and river.

\section{ACKNOWLEDGMENTS}

Our deep appreciation to Indonesia Ministry of Education and Culture, for giving research Grant of "Penelitian Dosen Pemula/PDP" for this research, which is part of activity in Urban and Regional Planning Department, University of Muhammadiyah Banjarmasin. 


\section{REFERENCES}

[1] B. Goenmiandari, J. Silas, and R. Supriharjo, "Konsep Penataan Permukiman Bantaran Sungai di Kota Banjarmasin berdasarkan Budaya Setempat," in Seminar Nasional Perumahan Permukiman Dalam Pembangunan Kota, 2010, pp. 1-14.

[2] Rochgiyanti, "Fungsi Sungai Bagi Masyarakat di Tepian Sungai Kuin Kota Banjarmasin," J. Komunitas, vol. 3, no. 1, pp. 51-59, 2011.

[3] C. Ye, L. Hu, and M. Li, "Urban green space accessibility changes in a high-density city: A case study of Macau from 2010 to 2015," J. Transp. Geogr., vol. 66, no. May 2017, pp. 106-115, 2018, doi: 10.1016/j.jtrangeo.2017.11.009.

[4] H. M. Caesarina, N. Humaida, M. F. Amali, and M. W. Wahyudi, "The Need of Green Open Spaces as the Effect of Urban Waterfront Development in Sungai Bilu, a Stream Corridor Neighbourhood in Banjarmasin," MATEC Web Conf., vol. 280, p. 03015, 2019, doi: 10.1051/matecconf/201928003015.

[5] H. M. Caesarina and N. Aina, "Green Space Impacts in Stream Corridor Settlement as an Effort to Form a 'Greener' Neighborhood," ESE Int. J. (Environmental Sci. Eng., vol. 1, no. 1, pp. 1-5, 2018.

[6] Direktorat Jendral Penataan Ruang. Department Pekerjaan Umum, Pedoman Penyediaan Dan Pemanfaatan Ruang Terbuka Hijau Di Kawasan Perkotaan. 2008, p. 84 p.

[7] W. Banjarmasin, Peraturan Daerah Kota Banjarmasin no.5 tahun 2016 tentang Rencana Pembangunan Jangka Menengah Daerah tahun 2016-2021. Indonesia, 2016.

[8] D. Vollmer and A. Grêt-Regamey, "Rivers as municipal infrastructure: Demand for environmental services in informal settlements along an Indonesian river," Glob. Environ. Chang., vol. 23, no. 6, pp. 1542-1555, 2013, doi: 10.1016/j.gloenvcha.2013.10.001.

[9] M. Lennon, M. Scott, and E. O’Neill, "Urban Design and Adapting to Flood Risk: The Role of Green Infrastructure,” J. Urban Des., vol. 19, no. 5, pp. 745-758, 2014, doi: 10.1080/13574809.2014.944113.

[10] C. R. Thorne, E. C. Lawson, C. Ozawa, S. L. Hamlin, and L. A. Smith, "Overcoming uncertainty and barriers to adoption of Blue-Green Infrastructure for urban flood risk management," J. Flood Risk Manag., vol. 11, pp. S960-S972, 2018, doi: 10.1111/jfr3.12218.
[11] N. G. Wright, Co. R. Thorne, and E. Lawson, "Delivering and evaluating the multiple flood risk benefits in Blue-Green cities: An interdisciplinary approach," in 11th International Conference on Hydroinformatics HIC 2014, New York City, USA, 2014, vol. 184, pp. 113-124, doi: 10.2495/FRIAR140101.

[12] F. G. Project, "a Floating Gardens Project," Floating Gardens Projects - Save Lake Atitian, 2018. http://savelakeatitlan.com/floating-gardensproject/ (accessed Sep. 20, 2018).

[13] U. Thinking and F. O. R. Limited, "Floating Gardens , Giant Chalkboards , and Climbing Walls on Banks of Seine in Paris.” pp. 1-20, 2018.

[14] H. M. Caesarina, "Green Space Conceptual Design for the Neighbourhood of Settlements along Martapura River in Banjarmasin," Ruang, vol. 6, no. 1, pp. 1-10, 2020 .

[15] F. Li, R. Wang, J. Paulussen, and X. Liu, "Comprehensive concept planning of urban greening based on ecological principles: A case study in Beijing, China," Landsc. Urban Plan., vol. 72, no. 4, pp. 325-336, 2005, doi: 10.1016/j.landurbplan.2004.04.002.

[16] M. Maks and S. Hirmer, "The potential for vertical gardens as evaporative coolers : An adaptation of the "Penman Monteith Equation ,"' Build. Environ., vol. 92, pp. 135-141, 2015, doi: 10.1016/j.buildenv.2015.03.033.

[17] S. M. Pradhanang, T. Boving, and E. Meisinger, "Floating Wetlands System: A viable alternative for water pollutants remediation," in MATEC Web of Conferences, 2019, vol. 5001.

[18] D. R. Rahmani, G. T. Noweg, H. M. Caesarina, W. Wahyunah, and K. P. Sari, "Urban Floating Farming Implementation: Introduction of Techniques and Modification as an Alternative to Farmers in the Acid Peatlands of the Suburbs," Comment an Int. J. Community Dev., vol. 2, no. 2, pp. 45-49, 2020.

[19] U. Rivers, "Floating Gardens in the Chicago River," 2019.

https://www.kickstarter.com/projects/wildmile/floa ting-gardens-in-the-chicago-river (accessed Feb. 05, 2019).

[20] S. Bajoria, "Floating Gardens," Green My Life, $2015 . \quad$ https://www.greenmylife.in/floatinggardens/ (accessed Sep. 20, 2018).

[21] Z. Edelson, "Uppsala Builds Floating Pocket Park to Promote Urban Farming," Metropolis, 2018. https://www.metropolismag.com/cities/uppsalabuilds-floating-pocket-park-promote-urbanfarming/ (accessed Sep. 20, 2018). 
[22] C. Y. Jim and S. S. Chen, "Comprehensive greenspace planning based on landscape ecology principles in compact Nanjing city, China," Landsc. Urban Plan., vol. 65, no. 3, pp. 95-116, 2003.

[23] P. Wirth, J. Chang, R. U. Syrbe, W. Wende, and T. $\mathrm{Hu}$, "Green infrastructure: a planning concept for the urban transformation of former coal-mining cities,” Int. J. Coal Sci. Technol., vol. 5, no. 1, pp. 78-91, 2018, doi: 10.1007/s40789-018-0200-y.

[24] A. Alves, B. Gersonius, Z. Kapelan, Z. Vojinovic, and A. Sanchez, "Assessing the Co-Benefits of green-blue-grey infrastructure for sustainable urban flood risk management," J. Environ. Manage., vol. 239, pp. 244-254, 2019.

[25] T. Kuzniecow Bacchin, R. Ashley, D. F. Sijmons, C. Zevenbergen, and A. Van Timmeren, "Greenblue multifunctional infrastructure: An urban landscape system design new approach," 2014.

[26] E. Andersson et al., "Enabling green and blue infrastructure to improve contributions to human well-being and equity in urban systems," Bioscience, vol. 69, no. 7, pp. 566-574, 2019. 